\title{
Effect of Watering Regimes and Water Quantity on the Early Seedling Growth of Picralima nitida (Stapf)
}

\author{
Gbadamosi Alaba Emmanuel $^{1}$ \\ ${ }^{1}$ Department of Plant Science \& Biotechnology, Adekunle Ajasin University, Nigeria \\ Correspondence: Gbadamosi Alaba Emmanuel, Department of Plant Science \& Biotechnology, Adekunle Ajasin \\ University, Nigeria. Tel: 234-806-356-7002. E-mail: gbadamosialabae@hotmail.com
}

Received: July 30, 2013 Accepted: February 8, 2014 Online Published: February 24, 2014

doi:10.5539/sar.v3n2p35 URL: http://dx.doi.org/10.5539/sar.v3n2p35

\begin{abstract}
Competing land use pattern has necessitated planting of useful forest trees on marginal lands with varying water status. A study was conducted on the effect of watering regimes and water quantity on seedlings growth of $P$. nitida. Seedlings were raised from seeds, transplanted in polythene bags and subjected to watering at full capacity daily, once in 3 days, 5 days; $20 \mathrm{ml}$ daily, 3 days, 5 days; $15 \mathrm{ml}$ daily, 3 days, 5 days; $10 \mathrm{ml}$ daily, 3 days, 5 days; and flooding. The growth traits assessed were plant height, collar diameter, number of leaves; shoot, root and leaf dry weights as well as leaf area. The effect of watering regime and water quantity were significant $(\mathrm{P} \leq$ 0.05 ) on quantitative morphological parameters of seedlings. Total dry weight and root dry weight were lower in both water-stressed and waterlogging than well-watered conditions, but the lowest values were obtained under flooding. However, specific leaf area (SLA) and leaf area ratio (LAR) were higher in water-stressed conditions than well-watered conditions. Relative growth rate of seedlings is related more to the net assimilation rate values than LAR and SLA. Also, root/shoot ratio was highest under daily full capacity watering. Thus, daily watering at full capacity with water availability or $15-20 \mathrm{ml}$ of water per seedling during scarcity is recommended for raising P. nitida seedlings.
\end{abstract}

Keywords: watering regime, biomass, trait, Picralima nitida

\section{Introduction}

The changing weather conditions triggered by climatic change have elicited diverse reactions from plants and animals. The changing rainfall pattern with its attendant unpredictable flooding and drought conditions around the globe necessitates a new approach to research in regeneration of useful forest species.

Water is an important factor in the growth, development and productivity of plants. Hartmann et al. (2005) reported that water stress due to drought is the most significant abiotic factor limiting plant growth and development. Water stress drastically decreased fresh and dry weight, leaf number, total leaf area and stomatal conductance (Vandoorne et al., 2012). However, the present realities favoured irrigation of food crops to feed the ever increasing human population at the expense of tree species; some of which have direct impact on the food, health and general well-being of rural communities.

Plant species respond differently to water availability, also, different plant parts adapt differently to varying water stress conditions. Seeds of many crop species are sensitive to flooding stress during germination (Sesay, 2009; Wuebker et al., 2001; Sung, 1995); whileprolonged flooding eliminates some species yetfavour others (Van der Valk, 1994 cited in Casanova \& Brock (2000)). Seabloom et al. (2001) opined that the depth of flooding can also have significant effect on species composition and biomass of establishing plants. Roots play an important role in plant survival during periods of drought (Hoogenboom et al., 1987). Hsiao and Xu (2000) reported that under water deficiency, growth is readily inhibited and growth of roots is favoured over that of leaves. Often, leaves of plants growing in water stressed environment are small both in number and size.

Thestudy species Picralimanitida is a tropical tree of the family Apocynaceae. Its parts are highly medicinal, the dried seeds are used in traditional medicine throughout West Africa; the seeds are crushed or powdered and taken orally, and are mainly used for the treatment of malaria (Kapadia et al., 1993). Duwiejua et al. (2002) reported that the seed contain a mixture of alkaloids producing antipyretic and anti-inflammatory effects along with analgesia. Extracts of the seeds have been reported to have opioid activity in five alkaloids namely akuammidine, 
akuammine, akuammicine, akuammigine and pseudoakuammigine (Meenzies et al., 1998).

This useful species occurs only in the wild under no form of management but with a threat of extinction, as part of the domestication strategy therefore; this study was carried out to determine the water requirements at the nursery for its subsequent inclusion in agro ecosystem.

\section{Materials and Method}

Mature fruits of Picralimanitida were collected from Benin City, Nigeria (lat. $6^{\circ} 23^{\prime} \mathrm{N}$ and long. $5^{\circ} 13^{\prime} \mathrm{E}$ ). Seeds were extracted from the fermented fruits manually and the seed coats removed to hasten germination (Gbadamosi, 2013); thereafter sown in washed river sand. The experiment was set up at the National Centre for Genetic Resources and Biotechnology, Moor plantation; Ibadan, Nigeria (lat. $7^{\circ} 24^{\prime} \mathrm{N}$ and long. $3^{\circ} 49^{\prime} \mathrm{E}$ ) in August 2011. At the two-leaf stage, young seedlings were transplanted into medium sized polythene bags measuring 12 $\times 14 \times 16 \mathrm{~cm}$ and allowed to wean under shade for three weeks and watered daily.

Later, seedlings were laid out in completely randomized design in the glasshouse. The following irrigation regimes and water quantity were administered to the seedlings viz: watering at full capacity daily; watering at full capacity once every 3 days; watering at full capacity once every 5 days; $20 \mathrm{ml}$ daily watering; $15 \mathrm{ml}$ daily; $10 \mathrm{ml}$ daily; $20 \mathrm{ml}$ once every 3 days; $15 \mathrm{ml}$ once every 3 days; $10 \mathrm{ml}$ once every 3 days; $20 \mathrm{ml}$ once every 5 days; $15 \mathrm{ml}$ every 5 days; $10 \mathrm{ml}$ every 5 days; and flooding. There were 15 single-plant replicates under each treatment. Flooding condition was accomplished by placing each seedling inside a bowl filled with water which was regularly replenished.

Growth parameters such as height, collar diameter, number of leaves and internode length were measured fortnightly for 5 months. Height of the seedlings were measured from the collar to the tip of the apical bud using a ruler calibrated in centimeter, collar diameter readings were taken using venier caliper while the number of leaves of each seedling were counted and recorded. At 3 months after transplanting, three seedlings were randomly selected every fortnight under each irrigation treatment for biomass assessment. These seedlings were separated into root and shoot components. The leaf area of each seedling was determined using the Leaf Area Meter. The root and shoot components of each seedling were put into separate envelopes for ease of identification. Each envelope was weighed using an electronic weighing balance to determine the fresh weight of the samples after which the envelopes together with their contents were oven dried for $24 \mathrm{~h}$ at $80{ }^{\circ} \mathrm{C}$. The samples were reweighed to get the dry weights. The data obtained were subjected to ANOVA, using statistical analysis system (SAS 9.1) and means were separated using Duncan's Multiple Range Test (DMRT) at 5\% level of significance.

The raw data were used to calculate the following growth parameters:

$$
\text { NAR (Net assimilation rate })=\frac{(\text { dry weight at end }- \text { dry weight at start })\left(\log _{\mathrm{e}} \text { leaf areaat end }-\log _{\mathrm{e}} \text { leaf area at start }\right)}{\text { (time at end }- \text { time at start })(\text { leaf area at end }- \text { leaf area at start })}
$$

$$
\begin{aligned}
\operatorname{RGR}_{\mathrm{DW}}(\text { Relative growth rate by dry weight }) & =\frac{\ln (\text { dry weight at end })-\ln (\text { dry weight at start })}{\text { duration of experiment }} \\
\mathrm{RGR}_{\mathrm{LA}}(\text { Relative growth rate by leaf area }) & =\frac{\ln (\text { leaf area at end })-\ln (\text { leaf area at start })}{\text { duration of experiment }} \\
\text { SLA }(\text { Specific leaf area }) & =\frac{\text { leaf area }}{\text { dry leaf biomass }} \\
\text { LAR (Leaf area ratio }) & =\frac{\text { leaf area }}{\text { dry plant biomass }} \\
\operatorname{RSR}(\text { Root : shoot ratio }) & =\frac{\text { dry root biomass }}{\text { dry shoot biomass }}
\end{aligned}
$$

\section{Result}

\subsection{Seedlings Height}

The effect of watering regime and water quantity were significant $(\mathrm{P} \leq 0.05)$ on the height of seedlings (Table 1). Overall, seedlings watered with $10 \mathrm{cl}$ at 3 days interval had the highest mean value of $13.17 \mathrm{~cm}$; this was 
followed by seedlings which received $20 \mathrm{cl}$ of water daily with a mean value of $12.85 \mathrm{~cm}$ while the lowest mean value of $8.5 \mathrm{~cm}$ was obtained from seedlings subjected to flooding. The mean height of seedlings subjected to flooding is significantly different from the mean value of seedlings under other treatments (Table 2). Height of seedlings was highly correlated with the number of leaves (Table 3 ).

Table 1. Summary of analysis of variance for growth variables of seedlings of P. nitida under different watering regimes and water quantities

\begin{tabular}{|c|c|c|c|c|c|c|c|c|c|}
\hline & & Height & & $\begin{array}{l}\text { Collar } \\
\text { diameter }\end{array}$ & & $\begin{array}{l}\text { Number } \\
\text { leaves }\end{array}$ & & $\begin{array}{l}\text { Internode } \\
\text { length }\end{array}$ & \\
\hline SV & $\mathrm{df}$ & MS & $\mathrm{F}$ & MS & F & MS & $\mathrm{F}$ & MS & $\mathrm{F}$ \\
\hline Treatment & 12 & 207.82 & $7.47^{*}$ & 172.59 & $0.96^{\mathrm{nS}}$ & 195.33 & $13.31^{*}$ & 6.3 & $10.78^{*}$ \\
\hline Error & 1937 & 27.82 & & 179.14 & & 14.68 & & 0.58 & \\
\hline Total & 1949 & & & & & & & & \\
\hline
\end{tabular}

* significantly different at 5\% probability; ns- not significantly different at $5 \%$.

Keys: SV- Source of variation; MS- Mean square; F- F value.

\subsection{Internode Length}

There were significant differences in internode length of seedlings due to watering regime and water quantity (Table 1). Seedlings which received $10 \mathrm{cl}$ of water at 3 days interval had the mean value of $2.24 \mathrm{~cm}$, those that were watered with $10 \mathrm{cl}$ daily followed with a mean value of $2.05 \mathrm{~cm}$ while seedlings watered at full capacity daily had the lowest mean value of $1.60 \mathrm{~cm}$. The mean internode length of seedlings that received $10 \mathrm{cl}$ of water at 3 days interval was significantly different from the values of seedlings under other treatments (Table 2). There were positive correlations among growth variables assessed (Table 3).

Table 2. Means and standard errors of growth variables of seedlings of $P$. nitida under different watering regimes and watering quantities

\begin{tabular}{lllll}
\hline Treatment & Height & Collar diameter & Number of leaves & Internode length \\
\hline FC daily & $12.16^{\mathrm{a}} \pm 0.43$ & $4.55^{\mathrm{a}} \pm 0.09$ & $9.23^{\mathrm{a}} \pm 0.31$ & $1.60^{\mathrm{d}} \pm 0.05$ \\
FC 3 days & $12.04^{\mathrm{a}} \pm 0.47$ & $4.39^{\mathrm{a}} \pm 0.09$ & $8.94^{\mathrm{a}} \pm 0.34$ & $1.64^{\mathrm{d}} \pm 0.05$ \\
FC 5 days & $12.70^{\mathrm{a}} \pm 0.46$ & $4.42^{\mathrm{a}} \pm 0.1$ & $9.38^{\mathrm{a}} \pm 0.32$ & $1.66^{\mathrm{d}} \pm 0.05$ \\
$20 \mathrm{cl}$ daily & $12.85^{\mathrm{a}} \pm 0.45$ & $4.43^{\mathrm{a}} \pm 0.09$ & $9.33^{\mathrm{a}} \pm 0.32$ & $1.65^{\mathrm{d}} \pm 0.05$ \\
$15 \mathrm{cl}$ daily & $12.72^{\mathrm{a}} \pm 0.45$ & $4.19^{\mathrm{a}} \pm 0.93$ & $8.59^{\mathrm{a}} \pm 0.33$ & $1.76^{\mathrm{d}} \pm 0.08$ \\
$10 \mathrm{cl}$ daily & $12.79^{\mathrm{a}} \pm 0.42$ & $4.38^{\mathrm{a}} \pm 0.10$ & $9.23^{\mathrm{a}} \pm 0.31$ & $2.05^{\mathrm{b}} \pm 0.07$ \\
$20 \mathrm{cl}$ 3 days & $12.31^{\mathrm{a}} \pm 0.43$ & $4.30^{\mathrm{a}} \pm 0.10$ & $9.41^{\mathrm{a}} \pm 0.33$ & $1.60^{\mathrm{d}} \pm 0.06$ \\
$15 \mathrm{cl} 3$ days & $12.41^{\mathrm{a}} \pm 0.46$ & $4.31^{\mathrm{a}} \pm 0.10$ & $9.25^{\mathrm{a}} \pm 0.32$ & $2.01^{\mathrm{b}} \pm 0.07$ \\
$10 \mathrm{cl} 3$ days & $13.17^{\mathrm{a}} \pm 0.41$ & $4.35^{\mathrm{a}} \pm 0.09$ & $9.39^{\mathrm{a}} \pm 0.32$ & $2.24^{\mathrm{a}} \pm 0.08$ \\
$20 \mathrm{cl} 5$ days & $12.15^{\mathrm{a}} \pm 0.47$ & $4.14^{\mathrm{a}} \pm 0.11$ & $8.46^{\mathrm{a}} \pm 0.33$ & $1.59^{\mathrm{d}} \pm 0.05$ \\
15 cl 5 days & $12.84^{\mathrm{a}} \pm 0.45$ & $4.21^{\mathrm{a}} \pm 0.11$ & $9.01^{\mathrm{a}} \pm 0.33$ & $1.75^{\mathrm{cd}} \pm 0.07$ \\
$10 \mathrm{cl} 5$ days & $12.73^{\mathrm{a}} \pm 0.45$ & $4.27^{\mathrm{a}} \pm 0.10$ & $9.17^{\mathrm{a}} \pm 0.33$ & $1.78^{\mathrm{cd}} \pm 0.07$ \\
Flooding & $8.5^{\mathrm{b}} \pm 0.13$ & $4.40^{\mathrm{a}} \pm 0.06$ & $5.15^{\mathrm{b}} \pm 0.11$ & $1.90^{\mathrm{bc} \pm 0.06}$ \\
\hline
\end{tabular}

* Mean values with the same letter in a column are not significantly different at $5 \%$ probability. 
Table 3. Correlation analysis of growth variables of seedlings of $P$. nitida under different watering regimes and water quantities

\begin{tabular}{lllll}
\hline Parameter & Height & Collar diameter & Number of leaves & Internode length \\
\hline Height & - & 0.11 & 0.91 & 0.13 \\
Collar diameter & 0.11 & - & 0.11 & 0.01 \\
Number of leaves & 0.91 & 0.11 & - & 0.06 \\
Internode length & 0.13 & 0.01 & 0.06 & - \\
\hline
\end{tabular}

\subsection{Number of Leaves}

Number of leaves differed significantly $(\mathrm{P} \leq 0.05)$ among seedlings subjected to different watering regimes and water quantity (Table 1). The highest number of leaves (9.41) was obtained in seedlings watered with $20 \mathrm{cl}$ of water at 3 days interval; which was followed by seedlings which received $10 \mathrm{cl}$ of water at 3 days interval with a mean value of 9.39 while the lowest value of 5.15 was obtained in seedlings grown under flooding conditions. The mean number of leaves of seedlings under flooding was significantly different from those of seedlings under other treatments (Table 2). Number of leaves was highly correlated with the height of seedlings (Table 3 ).

\subsection{Collar Diameter}

Collar diameter of seedlings were not significantly $(\mathrm{P} \leq 0.05)$ different under watering regime and water quantity. Seedlings watered daily at full capacity had the highest mean value of $4.55 \mathrm{~cm}$; this was followed by seedlings which received $20 \mathrm{ml}$ water daily $(4.43 \mathrm{~cm})$. The lowest mean value of $4.14 \mathrm{~cm}$ was obtained in seedlings which received $20 \mathrm{ml}$ of water 5 days interval $(4.14 \mathrm{~cm})$ (Table 2). Collar diameter was positively correlated with other growth parameters assessed (Table 3).

\subsection{Biomass of Seedlings}

\subsubsection{Shoot Dry Weight (SDW)}

The effect of water quantity and watering regime were significant $(\mathrm{P} \leq 0.05)$ on SDW of P. nitida (Table 4). Seedlings watered daily with $20 \mathrm{ml}$ water had the highest mean SDW of $2.29 \mathrm{~g}$ followed by seedlings under 15 $\mathrm{ml}$ daily and $10 \mathrm{ml}$ in 3 days watering with a mean value of $2.03 \mathrm{~g}$. Seedlings under flooding condition had the lowest mean value of $1.15 \mathrm{~g}$. There were significant differences in mean SDW values of seedlings watered daily with $20 \mathrm{ml}$ and those given $10 \mathrm{ml}$ in 5 days and seedlings under flooding condition (Table 5). SDW was highly correlated with RDW, LDW and TDW (Table 6).

Table 4. Summary of analysis of variance for biomass parameters of seedlings of $P$. nitida under different watering regimes and water quantities

\begin{tabular}{llllll}
\hline Parameter & SV & DF & MS & F & Pr $>$ F \\
\hline \multirow{3}{*}{ SDW } & Treatment & 12 & 1.87 & $2.33^{*}$ & 0.0073 \\
& Error & 182 & 1.41 & & \\
& Total & 194 & & & \\
& Treatment & 12 & 3.82 & $2.46^{*}$ & 0.0054 \\
RDW & Error & 182 & 1.55 & & \\
& Total & 194 & & & \\
& Treatment & 12 & 9.64 & $4.58^{*}$ & $<0.0001$ \\
LDW & Error & 182 & 2.11 & & \\
& Total & 194 & & & \\
& Treatment & 12 & 35.32 & $2.65^{*}$ & 0.0027 \\
TDW & Error & 182 & 13.32 & & \\
& Total & 194 & & & \\
& Treatment & 12 & 121070.49 & $8.20^{*}$ & $<0.0001$ \\
LA & Error & 182 & 14771.28 & & \\
& Total & 194 & & & \\
\hline
\end{tabular}

*Significantly different at $\mathrm{P} \leq 0.05$

Keys: SV- Source of variation; MS- Mean square; F- F value. 


\subsubsection{Root Dry Weight (RDW)}

There were significant $(\mathrm{P} \leq 0.05)$ differences in RDW of seedlings under varying watering regime and quantity (Table 4). The highest mean value of $2.85 \mathrm{~g}$ was recorded in seedlings watered daily at full capacity; seedlings which received $15 \mathrm{ml}$ of water in 3days had a mean value of $2.47 \mathrm{~g}$ while the lowest value of $1.25 \mathrm{~g}$ was obtained in seedlings under flooding. The mean RDW of seedlings watered daily at full capacity was significantly different from those under flooding, $15 \mathrm{ml}$ and $10 \mathrm{ml}$ in 5 days (Table 5). RDW is highly correlated with LDW and TDW of seedlings (Table 6)

\subsubsection{Leaf Dry Weight (LDW)}

The effect of water quantity and watering regime were highly significant $(\mathrm{P} \leq 0.05)$ on LDW of $P$. nitida seedlings (Table 4). Seedlings which received $10 \mathrm{ml}$ of water daily had the highest mean value of $4.09 \mathrm{~g}$, this was followed by seedlings watered at full capacity every 5days with a mean value of $4.05 \mathrm{~g}$. The lowest mean value of $1.58 \mathrm{~g}$ was obtained in seedlings under flooding condition. The mean LDW of seedlings watered at full capacity every 5 days and those watered daily with $10 \mathrm{ml}$ were significantly different from that watered with $10 \mathrm{ml}$ every 5 days and flooded seedlings (Table 5). LDW of seedlings had positive correlation with SDW, RDW and TDW.

Table 5. Means and standard errors of biomass parameters of seedlings of $P$. nitida under different watering regimes and water quantities

\begin{tabular}{|c|c|c|c|c|c|}
\hline Treatment & SDW (g) & RDW (g) & LDW (g) & TDW (g) & $\mathrm{LA}\left(\mathrm{cm}^{2}\right)$ \\
\hline FC daily & $1.86^{\mathrm{abc}} \pm 0.23$ & $2.85^{\mathrm{a}} \pm 0.36$ & $3.91^{\mathrm{ab}} \pm 0.37$ & $8.63^{a} \pm 0.85$ & $363.39^{\mathrm{abc}} \pm 33.64$ \\
\hline FC 3 & $.62^{\mathrm{abc}} \pm 0.31$ & $1 .{ }^{\mathrm{cd} 3} \pm 0.24$ & $3.35^{\mathrm{abcd}} \pm 0.37$ & $6.5^{\mathrm{abcd}} \pm 0.81$ & $374.15^{\mathrm{ab}} \pm 29.95$ \\
\hline FC 5 days & $88^{\mathrm{abc}} \pm 0.35$ & $2.11^{\mathrm{abcd}} \pm 0.38$ & $4.05^{\mathrm{a}} \pm 0.54$ & $8.05^{\mathrm{ab}} \pm 1.24$ & -52.84 \\
\hline $20 \mathrm{cl}$ daily & $.29^{\mathrm{a}} \pm 0.35$ & $2.46^{\mathrm{ab}} \pm 0.36$ & $3.82^{\mathrm{ab}} \pm 0.33$ & $8.57^{\mathrm{a}} \pm 1.00$ & $410.6^{\mathrm{a}} \pm 13.52$ \\
\hline $15 \mathrm{cl}$ & $.03^{\mathrm{ab}} \pm 0.31$ & $1.94^{\mathrm{bca}} \pm 0.31$ & $3.42^{\mathrm{abc}} \pm 0.32$ & $7.39^{\mathrm{abc}} \pm 0.87$ & $310.25^{\mathrm{bc}} \pm 28.94$ \\
\hline $10 \mathrm{c}$ & $1.7^{\mathrm{abc}} \pm 0.29$ & $1{ }^{\mathrm{bcd}} 9 \pm 0.25$ & $4.09^{\mathrm{a}} \pm 0.41$ & $7.69^{\mathrm{abc}} \pm 0.91$ & $413.85^{\mathrm{a}} \pm 37.30$ \\
\hline $20 \mathrm{c}$ & $1.58^{\mathrm{abc}} \pm 0.33$ & $2.07^{\mathrm{abcd}} \pm 0.38$ & $2.95^{\mathrm{bcde}} \pm 0.41$ & $6.60^{\mathrm{abcd}} \pm 1.06$ & $314.43^{\mathrm{bc}} \pm 38.89$ \\
\hline $15 \mathrm{c}$ & $1.99^{\mathrm{abc}} \pm 0.36$ & $2.47^{\mathrm{ab}} \pm 0.37$ & $3.43^{\mathrm{abc}} \pm 0.41$ & $7.88^{\mathrm{ab}} \pm 1.11$ & $279.47^{\mathrm{c}} \pm 21.63$ \\
\hline $10 \mathrm{cl} 3$ days & $2.03^{\mathrm{ab}} \pm 0.38$ & $2.41^{\mathrm{abc}} \pm 0.41$ & $3.57^{\mathrm{ab}} \pm 0.45$ & $8.01^{\mathrm{ab}} \pm 1.18$ & $308.65^{\mathrm{bc}} \pm 18.98$ \\
\hline $20 \mathrm{cl}$ & $1.81^{\mathrm{abc}} \pm 0.38$ & $1.63^{\mathrm{bcd}} \pm 0.37$ & $2.32^{\mathrm{det}} \pm 0.38$ & $5.75^{\mathrm{bcd}} \pm 1.08$ & $179.76^{\mathrm{d}} \pm 25.04$ \\
\hline $15 \mathrm{c}$ & $.29^{\mathrm{bc}} \pm 0.13$ & $1.45^{\mathrm{a}} \pm 0.18$ & $2.48^{\text {cdet }} \pm 0.25$ & $5.22^{\mathrm{cd}} \pm 0.47$ & $366.67^{\mathrm{abc}} \pm 34.85$ \\
\hline $10 \mathrm{cl} 5 \mathrm{~d}$ & 0.09 & $1.29^{\mathrm{d}} \pm 0.16$ & $2.17^{\mathrm{et}} \pm 0.20$ & $4.61^{\mathrm{d}} \pm 0.28$ & $376.4^{\mathrm{ab}} \pm 27.74$ \\
\hline Flooding & $1.15^{\mathrm{c}} \pm 0.31$ & $1.25^{\mathrm{a}} \pm 0.30$ & $1.58^{\mathrm{t}} \pm 0.32$ & $3.98^{\mathrm{d}} \pm 0.89$ & $125.06^{\mathrm{d}} \pm 24.85$ \\
\hline
\end{tabular}

Means with the same letter in a column are not significantly different.

Table 6. Correlation analysis of biomass parameters of seedlings of $P$. nitida under different watering regimes and water quantities

\begin{tabular}{llllll}
\hline Parameter & SDW & RDW & LDW & TDW & LA \\
\hline SDW & - & 0.81 & 0.79 & 0.92 & 0.24 \\
RDW & 0.81 & - & 0.81 & 0.94 & 0.26 \\
LDW & 0.79 & 0.81 & - & 0.94 & 0.5 \\
TDW & 0.92 & 0.94 & 0.94 & - & 0.37 \\
LA & 0.24 & 0.26 & 0.5 & 0.37 & - \\
\hline
\end{tabular}

\subsubsection{Total Dry Weight (TDW)}

The TDW of seedlings were significantly $(\mathrm{P} \leq 0.05)$ different under varying watering regimes and water quantities (Table 4). Seedlings watered at full capacity had the highest mean value of $8.63 \mathrm{~g}$ followed by seedlings that received $20 \mathrm{ml}$ of water daily $(8.57 \mathrm{~g})$. The lowest mean value of $3.98 \mathrm{~g}$ was obtained in seedlings under flooding conditions. The mean TDW of seedlings watered with $20 \mathrm{ml}$ of water; and at full capacity daily were significantly different from seedlings given 10,15 and $20 \mathrm{ml}$ water every 5 days; and those under flooding condition (Table 5). TDW had high positive correlation with SDW, RDW and LDW (Table 6). 


\subsubsection{Leaf Area (LA)}

The effect of water quantity and watering regime were significant $(\mathrm{P} \leq 0.05)$ on LA of seedlings (Table 4). Seedlings watered at full capacity every 5days had the highest mean LA value of $423.3 \mathrm{~cm}^{2}$ followed by seedlings which had $20 \mathrm{ml}$ of water daily with a mean value of $410.6 \mathrm{~cm}^{2}$. The lowest mean value of $125.06 \mathrm{~cm}^{2}$ was obtained in seedlings under flooding conditions. The mean LA value of seedlings under flooding and those watered with $20 \mathrm{ml}$ every 5 days were significantly different from other treatments (Table 5). Leaf area was lowly but positively correlated with SDW, RDW and TDW (Table 6).

\subsubsection{Relative Growth Rate by Dry Weight $\left(\mathrm{RGR}_{\mathrm{DW}}\right)$ and Leaf Area $\left(\mathrm{RGR}_{\mathrm{LA}}\right)$}

Relative growth rate $\left(\mathrm{RGR}_{\mathrm{DW}}\right)$ varied widely among treatments. The highest value of $0.0638 \mathrm{~g} / \mathrm{g} / \mathrm{wk}$ was obtained in seedlings watered at full capacity every 5 days while the lowest value of $-0.0391 \mathrm{~g} / \mathrm{g} / \mathrm{wk}$ was obtained in seedlings watered with $20 \mathrm{ml}$ every 5 days. RGR $_{\mathrm{LA}}$ values ranges from $-0.0824 \mathrm{~g} / \mathrm{g} / \mathrm{wk}$ in seedlings watered with $20 \mathrm{ml}$ of water every 5 days to $0.0635 \mathrm{~g} / \mathrm{g} / \mathrm{wk}$ in seedlings which had $20 \mathrm{cl}$ of water every 3 days (Table 7).

Table 7. Computed growth parameters of seedlings of P. nitida under different watering regimes and water quantities

\begin{tabular}{lllllll}
\hline Treatment & RGR $_{\text {Dw }}$ & RGR $_{\text {LA }}$ & SLA & LAR & NAR & RSR \\
\hline FC daily & 0.0412 & 0.0466 & 92.94 & 42.11 & $3.139 \times 10^{-4}$ & 1.53 \\
FC 3days & 0.0428 & 0.0051 & 111.68 & 57.56 & $2.420 \times 10^{-4}$ & 0.94 \\
FC 5days & 0.0638 & 0.0389 & 104.52 & 52.58 & $3.064 \times 10^{-4}$ & 1.12 \\
20 cl daily & 0.0325 & 0.0127 & 107.48 & 47.91 & $1.867 \times 10^{-4}$ & 1.07 \\
15 cl daily & 0.0626 & 0.0335 & 90.72 & 41.98 & 0.0031 & 0.95 \\
10 cl daily & 0.0408 & 0.0571 & 101.19 & 53.82 & $2.862 \times 10^{-4}$ & 1.12 \\
20 cl 3 days & 0.0367 & 0.0635 & 106.59 & 47.64 & $2.444 \times 10^{-4}$ & 1.31 \\
15 cl 3 days & 0.0561 & 0.0026 & 81.48 & 35.47 & $4.049 \times 10^{-4}$ & 1.24 \\
20 cl 5 days & -0.0391 & -0.0824 & 77.48 & 31.26 & $-2.556 \times 10^{-4}$ & 0.9 \\
15 cl 5 days & 0.0494 & 0.0286 & 147.85 & 70.24 & $2.689 \times 10^{-4}$ & 1.12 \\
10 cl 5 days & 0.0282 & -0.0249 & 173.27 & 81.64 & $1.831 \times 10^{-4}$ & 1.1 \\
Flooding & 0.0437 & -0.0661 & 79.14 & 31.42 & $1.737 \times 10^{-4}$ & 1.08 \\
\hline
\end{tabular}

\subsubsection{Root/Shoot Ratio (RSR)}

The ratio of root to shoot was highest in seedlings watered at full capacity daily (1.53), while the lowest RSR value of 0.9 was obtained in seedlings which received $20 \mathrm{ml}$ of water every 5 days (Table 7).

\subsubsection{Specific Leaf Area (SLA) and Leaf Area Ratio (LAR)}

Specific leaf area (SLA) values range from $79.14 \mathrm{~cm}^{2} / \mathrm{g}$ in flooded seedlings to $173.27 \mathrm{~cm}^{2} / \mathrm{g}$ in seedlings watered with $10 \mathrm{ml}$ in 5 days. LAR nearly followed the same pattern with values of $31.26 \mathrm{~cm}^{2} / \mathrm{g}$ and $81.64 \mathrm{~cm}^{2} / \mathrm{g}$ for seedlings watered with 20 and $10 \mathrm{ml}$ of water every 5 days respectively (Table 7).

\subsubsection{Net Assimilation Rate (NAR)}

Seedlings watered daily with $15 \mathrm{ml}$ of water had the highest value of $0.0031 \mathrm{~g} / \mathrm{cm}^{2} / \mathrm{wk}$, those watered with $15 \mathrm{ml}$ in 3 days had a value of $4.048 \times 10^{-4} \mathrm{~cm}^{2} / \mathrm{g}$ while a negative value of $-2.556 \times 10^{-4} \mathrm{~cm}^{2} / \mathrm{g}$ was obtained in seedlings given $20 \mathrm{ml}$ of water every 5 days (Table 7)

\section{Discussion}

Water is a major constituent of all living organisms which is involved in important biochemical processes including photosynthesis thus its availability in adequate quantity and at biologically tolerable interval affects productivity of plant species. In this study, total biomass and root dry weights were lower in both water stressed and water logging conditions than well-watered conditions; but the lowest values were obtained under waterlogging. Gonzales et al. (2009) made the similar observation for Chenopodium quinoa (Willd.). However, SLA and LAR were higher in drought conditions than well-watered conditions.

Seedlings of $P$. nitida which received the lowest water rate $(10 \mathrm{ml})$ at the longest intervals of 5 days had the lowest biomass value, this agreed with the findings of several authors that drought water stress influences plant 
growth and limits productions (Ky-Dembele et al., 2010; Hsiao \& Xu, 2000; Busso et al., 1998; Hampson \& Simpson, 1990). In this study, excess of water alsohad negative impact on growth and biomass production of the seedlings.This result agreed with the findings of Sakio (2005) that flooding reduces the total dry weight increment in some plant species.In flooding condition, available oxygen in the soil is usually low thus, limiting nutrient absorption for species not adapted to this condition; and as stated by Predick et al. (2009) growth of flood-intolerant species is often depressed in flooding. P. nitida is not a choice species for planting in flooded areas as seedlings were stunted and number of leaves and leaf expansion were very poor in line with the findings of Kozlowski (1997); this response might have reflected the species habitat and growth pattern as suggested by Sakio (2005).

It has been widely reported that extensive root growth is an adaptive feature under drought stressed conditions (Guoxiong et al., 2002); the result of the present study is contrary to this, root dry matter reduced under increased water deficit. The ratio of root to shoot was highest in seedlings under full capacity daily watering. This is in agreement with the finding of Vandoorne et al. (2012) that water stress drastically decreased fresh and dry root weight, leaf number, total leaf area and stomatal conductance in Cichoriumintybus (var: sativum).

There were some wide variations in RGR of seedlings among treatments; this is often adduced to variations in SLA (Cornelissen et al., 2003; Karacic \& Weih, 2006). Cornelissen et al. (1998) reported that RGR of deciduous species seems to be determined by their higher LAR, which in turn is accounted for by their higher SLA compared to evergreen. The result of the present study revealed that although $P$. nitida is a deciduous species, NAR is a better determinant of RGR as seedlings with higher SLA and LAR under water stress had very poor RGR values. Antunez et al. (2001) seems to support this by inferring that temporal variation in RGR within species was due mainly to variation in NAR.

Ordinarily, plants as part of their survival strategy to reduce water loss during periods of severe water stress may reduce leaf area or formation of new leaves; or shed old ones. Lawlor and Leach (1985) submitted that decrease in LA is a common effect of drought, in this study however, leaf area under the severest water stress tested compared reasonably with those under daily full capacity watering; this is perhaps due to the very waxy cuticle of the leaf.

\section{Conclusion}

The result from this study seems to suggest that $P$. nitida can be raised with some satisfactory growth under some form of water stress but cannot grow well in flooding conditions. Therefore, further investigation with longer periods of drought may help to reveal the drought resistance traits of this species. Also, these drought conditions would require field studies for verification.

\section{Acknowledgements}

This study was executed with support from International Foundation for Science (IFS) through research grantD/4670-1 (2009).

\section{References}

Antunez, I., Retamosa, E. C., \& Villar, R. (2001). Relative growth rate in phylogenetically related deciduous and evergreen woody species. Oecologia, 128, 172-180. http://dx.doi.org/10.1007/s004420100645

Busso, C. A., Fernandez, O. A., \& Fedorenko, D. E. F. (1998). Dry weight production and partitioning in Medicago minima and Erodiumcicutariumunder water stress. Annals of Botany, 82, 217-227. http://dx.doi.org/10.1006/anbo.1998.0667

Casanova, M. T., \& Brock, M. A. (2000). How do depth, duration and frequency of flooding influence the establishment of wetland plants communities? Plant Ecology, 147, 237-250. http://dx.doi.org/10.1023/A:1009875226637

Cornelissen, J. H. C., Cerabolini, B., Castro-Diez, P., Villar-Salvador, P., Montserrat-Marti, G., Puyravaud, J. P., ... Aerts, R. (2003). Functional traits of woody plants: correspondence of species rankings between field adults and laboratory-grown seedlings. Journal of Vegetation Science, 14(3), 311-322. http://dx.doi.org/10.1111/j.1654-1103.2003.tb02157.x

Cornelissen, J. H. C., Castro-Díez, P., \& Carnelli, A. C. (1998). Variation in relative growth rate among woody species: scaling up. In H. Lambers, H. Poorter, \& M van. Vuuren (Eds.), Inherent variation in plant growth: physiological mechanisms and ecological consequences (pp. 363-392). Backhuys, Leiden.

Duwiejua, M., Woode, E., \& Obiri, D. D. (2002). Pseudo-akuammigine, an alkaloid from Picralima nitida seeds, has anti-inflammatory and analgesic actions in rats. Journal of Ethnopharmacology, 81, 73-79. 
http://dx.doi.org/10.1016/S0378-8741(02)00058-2

Gbadamosi, A. E. (2013). Germination biology of Picralimanitida (Stapf) under pretreatments. Greener Journal of Biological Sciences, 3(1), 13-20.

Gonzales, J. A., Gallardo, M., Hilal, M., Rosa, M., \& Prade, F. E. (2009). Physiological responses of quinoa (Chenopodium quinoaWilld.) to drought and waterlogging stresses: dry matter partitioning. Botanical Studies, 50, 35-42.

Guoxiong, C., Krugman, T., Fahima, T., Korol, A. B., \& Nevo, E. (2002). Comparative study on morphological and physiological traits related to droughtresistance between xeric and mesicHordeumspontaneumlines in Isreal. Barley Genet. Newslett., 32, 22-33.

Hampson, C. R., \& Simpson, G. M. (1990). Effect of temperature, salt and osmotic potential on early growth of wheat (TrticumaestivumL.). I. Germination. Can. J. Bot., 68, 524-528. http://dx.doi.org/10.1139/b90-072

Hartmann, T., College, M., \& Lumsden, P. (2005). Responses of different varieties of Lolium perenneto salinity. Annual Conference of the Society for Experimental Biology, Lancashire.

Hoogenboom, G., Huck, M. G., \& Peterson, C. M. (1987). Root growth rate of soybean as affected bydrought stress. Agron J., 79, 607-614. http://dx.doi.org/10.2134/agronj1987.00021962007900040003x

Hsiao, T. C., \& Xu, L. (2000). Sensitivity of growth of roots versus leaves to water stress: biophysical analysis and relation to water transport. Journal of Experimental Botany, 51(350), 1595-1616. http://dx.doi.org/10.1093/jexbot/51.350.1595

Kapadia, G. J., Angerhofer, C. K., \& Ansa-Asamoah, R. (1993). Akuammine: an antimalarial indolemonoterpene alkaloid of Picralimanitida seeds. Planta Medica, 59(6), 565-566. http://dx.doi.org/10.1055/s-2006-959764

Karacic, A., \& Weih, M. (2006). Variation in growth and resource utilisation among eight poplar clones grown under different irrigation and fertilisation regimes in Sweden. Biomass andBioenergy, 30(2), 115-124.

Kozlowski, T. T. (1997). Responses of woody plants to flooding and salinity. Tree Physiol. Monogr, 1, 1-29.

Ky-Dembele, C., Bayala, J., Savadogo, P., Tigabu, M., Odén, P. C., \& Boussim, I. J. (2010). Comparison of growth responses of Khayasenegalensis seedlings and stecklings to four irrigation regimes. Silva Fennica, 44(5), 787-798.

Lawlor, D. W., \& Leach, J. E. (1985). Leafgrowthandwaterdeficits:biochemistry in relationto biophysics. In N. R. Baker, W. J. Davis \& C. K. Ong (Eds.), Control of Leaf Growth (pp. 267-294). England: CambridgeUniversityPress.

Meenzies, J. R., Paterson, S. J., Duwiejua, M., \& Corbett, A. D. (1998). Opioid activity of alkaloids extracted from Picralimanitida (fam. Apocynaceae). European Journal of Pharmacology, 350(1), 101-108. http://dx.doi.org/10.1016/S0014-2999(98)00232-5

Predick, K. I., Gergel, S. E., \& Turner, M. G. (2009). Effect of flood regime on tree growth in the floodplain and surrounding uplands of Wisconsin River. River Res. Applic., 25, 283-296. http://dx.doi.org/10.1002/rra.1156

Sakio, H. (2005). Effects of flooding on growth of seedlings of woody riparian species. J. Forest Research, 10(4), 341-346. http://dx.doi.org/10.1007/s10310-005-0156-9

Seabloom, E. W., Moloney, K. A., \& van der Valk, A. G. (2001). Constraints on the establishment of plants along a fluctuating water-depth gradient. Ecology, 82, 2216-2232. http://dx.doi.org/10.1890/0012-9658(2001)082[2216:COTEOP]2.0.CO;2

Sesay, A. (2009). Influence of flooding on Bambara groundnut (Vigna subterranean L.) germination: Effect of temperature, duration and timing. African Journal of Agricultural Research, 4(2), 100-106.

Sung, J. M. (1995). The effect of sub-optimal $\mathrm{O}_{2}$ on seedling emergence ofsoybean seeds of different size. Seed Sci. Technol, 23, 807-814.

Vandoorne, B., Mathieu, A. S., Van den Ende, W., Vergauwen, R., Perilleux, C., Javaux, M., \& Lutt, S. (2012). Water stress drastically reduces root growth and inulin yield in Cichoriumintybus (var. sativum) independently of photosynthesis. Journal of Experimental Botany, 63(12), 4359-4373. http://dx.doi.org/10.1093/jxb/ers095

Wuebker, E. F., Mullen, R. E., \& Koehler, K. (2001). Flooding and temperatureeffects on Soybean germination. Crop Sci., 41, 1857-1861. http://dx.doi.org/10.2135/cropsci2001.1857 


\section{Copyrights}

Copyright for this article is retained by the author(s), with first publication rights granted to the journal.

This is an open-access article distributed under the terms and conditions of the Creative Commons Attribution license (http://creativecommons.org/licenses/by/3.0/). 